\title{
The Execution Rights Of Dependents Online
}

\author{
I Nyoman Semadiartha*, I Nyoman Sujana and I Ketut Widia \\ Program Magister IImu Hukum, Universitas Warmadewa Denpasar. 2019. \\ *semadiartha@yahoo.com
}

\begin{tabular}{|l|}
\hline How to cite (in APA style): \\
Semadiartha, I, N., Sujana, I, N., Widia, I, K. (2020). The Execution Rights Of Dependents Online. Jurnal Hukum Prasada, \\
7(1), 8-13. doi: https://doi.org/10.22225/jhp.7.1.1085.8-13 \\
\hline
\end{tabular}

\begin{abstract}
The study was motivated by the increasingly influential technology against the executions carried out by the Bank as an alternative to the completion of bad debt. Online auction based on article 6, UUHT is the executable can cause conflict parate norms, because the existence of regulations implementing the Government-level, as article 26 UUHT, associated with article 7 (1) of law No. 12 of 2011. Parate executions required by Court Fiat. The theory is a theory of hierarchi theory of norms, legal certainty and the theory of legal protection. This study aims to examine the dependent object execution rights in the settlement effort as the execution parate bad debt at The Rural of Banks and to describe the legal protection for the winner of the auction as a result of the implementation of the execution rights of dependents. This type of research and the approach is normative, legal research with approach of legislation and cases. The result of this study gave conclusion on the dependent right execution parate conducted an online lender as an alternative to the last settlement of bad debt, for quick and efficient. Auction winner gets legal protection internally, because the lender makes a deal with the auction winner that the auction is legal transactions such as selling in General. External legal protection, the State provides legal protection to all parties in the execution of rights to dependents.
\end{abstract}

Keywords: Bad Debt, Parate Execution Online, legal protection

\section{INTRODUCTION}

The issue of economic development of Indonesia is based on the provisions of article 33 paragraph (1) of the 1945 Constitution Of Indonesia, as a joint venture on the basis of the principle of family. However in practice the business showed a range of competition, including those that are not healthy. In fact, it is not expected because it may cause negative consequences for economic development and public order as well as the public interest.

The Rural Bank as one financial institution has the role of setrategis in realizing a fair and prosperous society, for his efforts in running the Bank is organized a Community Fund and redistributes in the form of credit. Rural banks are special banks that are generally located in the district and sub-district areas and they are very involved in providing loans to MSBs (Anwar, Nidar, Komara, \& Layyinaturrobaniyah, 2019) Channeling Community Fund in the form of credit is the main activity for the Rural Bank.

The Rural Bank in the credit channel has to do with the principle of prudence (prudencial banking); starting from planning the assignment of credit, interest rates, credit granting procedures, analysis of credit granting, until the settlement of the troubled credit. On the one hand channelling of credit Activity is strategic functions for the bank as a revenue generator and on the other hand errors in channeling credit is also often the cause of losses a bank. Refund of already disbursed by the lender, is limited to borrowers with repayment period in accordance with the agreed upon both parties in agreement credit. 
Refund has been granted by the creditor to the debtor being fluent is not guaranteed, because it is bounded with timeframes, then required a guarantee or collateral in credit granting by the creditor to the debtor. To ensure the smooth running of the payment or repayment of money received by the debtor, the debtor's ordinary submit guarantees that set by the creditor to the debtor. This guarantee can be either goods moving or not moving. The Rural Bank of Credit disbursed very conventional in considering bail as a condition of credit which will be channeled. Refund of already disbursed by the lender, is limited to borrowers with repayment period in accordance with the agreed upon both parties in agreement credit. Refund has been granted by the creditor to the debtor being smooth is not guaranteed, because it is bounded with timeframes, then required a guarantee or collateral in credit granting by the creditor to the debtor. To ensure the smooth running of the payment or repayment of money received by the debtor, the debtor's ordinary submit guarantees that required by the creditor to the debtor. This guarantee can be either goods moving or not moving. The Rural of Banks disbursed very conventional in considering bail as a condition of credit which will be channeled.

In the completion of bad debt, the Rural of Banks by doing the execution of guarantee rights of a dependent as the last step when the debtor as the giver of Rights Dependent injury promises, generally with parate execution. Parate implementation execution in article 6 and article 20 of the Act No. 4 of the year 1996 is not set explicitly models the execution, so that the parties can choose the execution in accordance with his wishes. Execution rights of Dependents among the banking world as a process and the implementation of the resolution of bad debt problems are frequent, causing its implementation does not run as expected creditors as well as debtors. Dependent rights object execution can be done in 3 ways, among others (Pusoko, 2008):

the auction through KPKNL parate or execution.

The execution rights of Dependents through the decision of the District Court.

Sales under the hand.

According to (Badrulzaman, 2009) that execution rights of Dependents by the creditor, the creditor can in theory be carried out without asking for the determination of the District Court. However in practice this is not possible, because based on the provisions of article 1211 KUHPerdata that in order for the auction could be held is need for State Court determination letter. This is emphasized by the existence of the ruling of the Supreme Court No. 3210K/PDT/1984 which firmly establishes the ban for the auction Office to perform a execution dependent rights auction, without any State Court fiat (Badrulzaman, 2009). The implementation of the current auction, only regulated by regulation of the Minister of finance, in particular the execution not parate requires the presence of the fiat Chairman District Court (Badrulzaman, 2009). The existence of a system of auctions online (internet) as implementation of execution dependent upon Rights parate article 6 UUHT, indicated the existence of conflict is the norm. This is because the regulatory implementation-level existence yet government regulations as referred to article 26 UUHT and the provisions of article 7 paragraph 1 of the law No. 12 Year 2011 about the formation of legislation. So that raises the question, whether the implementation execution parate online of the object the rights of dependants may be said to be valid and binding on the parties because the procedure implementation of the auction was only set in a regulation of the Minister. The research problems are formulated into how setting the execution rights of Dependents in the completion of bad debt at the Rural of Banks? And how legal protection for the winners in the auction object execution rights to dependents who made online?

Based on the background, then the researcher wants to study about the dependent object execution rights in the settlement effort as the execution parate bad debt at The Rural of Banks and to describe the legal protection for the winner of the auction as a result of the implementation of the execution rights of dependents.

\section{METHODS}

This type of research is the normative law or doctrinal study (Soekanto \& Mamudji, 2001). Approach to the problem that is used in this research is the use of three (3) 
approaches, they are the approach of legislation (apprroah statute), a conceptual Approach, and the approach of the case (case approach) (Marzuki, 2009). In normative law or doctrinal study, data are collected through library research. It means that the researchers study document or laws that related to the problem discussed. The legal sources and materials used in this study was secondary legal material.

\section{RESULT AND DISCUSSION}

\section{Setting the Execution in a Credit Settlement Parate Problematic.}

The completion of bad debt at the Rural of Banks carried out using rules provided by law for creditors, among other things : If is through through public auction, then carried out by the District Court. The execution of the guarantee rights objects is done by order (fiat) the Chairman of the District Court as the implementation of the execution rights of a dependent who has the power of eksekutorial, it is then carried out executions of the object the tub next to dependents is done auctions in General.

Under article 20 (1) a jo UUHT article 6, that in execution, parate holders first dependents have the right to sell on its own power objects dependent rights in tort debtors (eigenmachtig verkoop van beding) as determined in article 11 (2) e UUHT.

Based on the application for execution by creditors, the official auction process implementation of auctions, beginning with the announcement of the auction twice followed by the auction sale and Division of auction proceeds. If the auction proceeds after deducting all fees and the payment of the debt to lenders there are still remaining, then the rest should be left to the giver of rights to dependents.

Based on the approach of legislation (the statute approach) over the execution of guarantee Land Rights vested in a settlement Dependent on troubled Rural of Bank and the protection of the law for the winner of the auction, which was conducted online or via the internet, it can be revealed the following things: 1). the rights of a dependent object execution Parate, is dependent upon the execution of object rights are most often performed by the lenders in this case banks, in particular Rural of Bank, because the procedure and the process is faster and more efficient. 2). Legal basis for the implementation of the execution parate set article 20 (1) a UUHT jo article 6 and article 11 (2) e UUHT. 3). The auction procedure dependent rights, still allow the enactment of article $224 \mathrm{HIR} /$ article $258 \mathrm{RBg}$, which expressly provided for in the General Explanation number 9 UUHT, because the provisions of execution under article 26 and the General Explanation number 9 UUHT stated have not been valid for There has been no regulation of its implementation. To prevent the occurrence of vacancy law then enforced the provisions of article $224 \mathrm{HIR} /$ article $258 \mathrm{RBg}$.

According to article 7 (1) of law No. 12 year 2011, implementation of the forms of regulation is Article 26 UUHT is Government Regulation. Procedures and the procedures of the auction was only set up in regulation of the Minister of Finance No. 27/PMK.06/2016 that determines procedures for auction, particularly parate execution can be done without State Court fiat. This showed the existence of conflict is the norm, where execution parate according to BAL, with fiat should be the District Court.

Concern among banking, well-grounded in the presence of UUHT, that; If the debtor tort, then object rights are sold through public auction dependents, with the rights of other creditors of the preceding payment of the receivable. This is a problem of inconsistency.

With the above problems in the science of law is known, some basic legal rules as guidelines, namely (Bruggink, 2015): the principle of lex superior derogat legi inferior, the principle of lex generalis derogat legi specialists who argued that the law is a special law which is the general exclusion, the principle lex posterior derogat legi priori new regulation means putting aside the old rules, the principle of legality or principle of law should not be retroactive (non-retroactive), basis of lex superior derogat. legi inferior meaning higher regulations rule out low (basis stufendbau) (Bruggink, 2015). Within the framework of thought concerning the type and the hierarchy of legislation, cannot be separated from the stuffenbau theory. With the approach of the case (case approach), over the ruling of the 
Tribunal Chief Justice of the Supreme Court RI with the verdict the number $2626 \mathrm{~K} /$ $\mathrm{Pdt} / 2014$, That procedure parate execution performed against the object of Cassation Respondent Rights by Dependants Service Office a wealth of Auction And auction is the implementation of the State is exercised according to the provisions of article 6 UUHT is a stand-alone provision regardless of the provisions concerning the execution of others.

The provisions of article $6 \mathrm{UUHT}$ is part of the execution of the provisions essentially parate set in article 20 (1) a UUHT in other words view KPKNL and BRI about the auction is a partial view of the execution. Parate ekskusi executed by the creditor refers to regulation of the Minister of finance Number 93/PMK. 06/2010, regarding the Auction Guidelines, and treatise Auction No. 1297/2011, dated September 29, 2011 that are published by KPKNL Semarang. This ruling, it ignores the stufenbau an attribute theory from Hans Kelsen, as set in the Act No. 12 Year 2011 about the formation of Regulations.

According to the researchers, the judge in deciding the matter above, prefer on expediency of the law within the community, so that it can provide legal certainty. This can we note the opinion of Jeremy Bentham, John Stuart Mill, and Rudolf von Jhering. Bentham stated that the purpose of the law is to give the maximum amount of happiness for mankind (Ali, 2015). Happiness should be good and do not interfere with someone else though emphasis in the happiness of the individual. While John Stuart Mill as a follower of Bentham gave a somewhat different arguments with Bentham, who stated, usefulness, justice between individuals, and the general public are inter-related. The law will be good and useful if based on the sense of Justice, human beings tend to be upset if you can't obtain happiness (Ali, 2015). Meanwhile in man there is a sense of social that can cure upper Shannan he obtained no happiness, with that so there was an element of self defense which is a natural and sympathy (Ali, 2014).

\section{Legal protection for the auction winner parate Execution Online.}

The winner of the auction is well intentioned buyers should get legal protection. In practice being vague and there is no certainty, if the Legislation does not exist or is not complete. Resolve the issue, the judge will act on its own initiative to resolve the matter. Judges will play an active role to determine or set and decide on the matter, although existing legislation did not organize it, incomplete or obscurity, by conducting legal discovery (rechtsvinding) (Ali, 2015).

According to (Marzuki, 2009), the discovery that the law covers the activities of the judges do the formation of law (rechtsvorming), analogy (rechtsanalogie), a softening of law (rechtsverfijning), law or interpretation (interpretatie). The presence of the judge's action this can provide legal protection external to the winner of the auction. Judges in applying the legislation which set about the execution is parate legal material, namely article 6 UUHT, then in law execution, because parate formyl parate execution only regulated in the ministerial regulation is the reason the dispute from the applicant's Cassation.

Legal protection is obtained for the winner of the auction is the same as the buyer of the land and buildings or in good faith, a treatise in the form of an auction, which has the force of law equal to the deed of sale and purchase. Understanding the auction is a Treatise as evidence of the implementation of the auction. Auction officials make the auction event news article 85 paragraph (1) the regulation of the Minister of finance Number 27/PMK. 06/2016. Under article 35 of the regulation number 1 Minister of finance Number 27/PMK. 06-2016, the treatise is Auction news auction event implementation made by officials of the Auction as an authentic deed and has the power of proof. In the event the auction contains a news blurb about everything related to the implementation of a general sales or auctions conducted by the officials of the auction.

The treatise that auction should contain what, why, where, when, how, and anyone involved in the implementation of the auction. Beside that describes the object over the stuff auctioned and conducted the auction, ranging from background until the onset of the auction. Then explain where the auction is carried out and when the auction is carried out as well as the process of offer of up to on designated auction winner. And last the parties involved in the auction, bidders and buyers, the applicant auction. Thus the treatise land auction is an authentic deed that its shape is already specified laws, made by or in the 
presence of Public officials.

According to (Isnaeni, 2016) that, protection of the law in terms of the source can be distinguished into two (2) kinds of legal protection among other things internal and external legal protection (Isnaeni, 2016). Internal, legal protection is protection of law made by the parties at the time of making the agreement, in which at the time made a clause-clause of the agreement, the parties wanted the interested to be accommodated on the basis of their agreement.

Likewise, any kind of risk can be prevented through laboured from filings with securities, and through the clause-clause which is made on the basis of mutual agreement. So with the clause that the parties would gain a balanced legal protection over their approval. So this new internal legal protection can be realized by the parties, their legal position in a relatively balanced, in which the parties have had bargaining power are balanced. Based on the principle of freedom of contracts each party which makes the Treaty has discretion to declare the will fit his interests. The basis of this agreement made the runway at the time the parties drawing up clause-clause of the agreement that is being made, so that the legal protection of the parties can be realized on the initiative at the time of making the agreement (Isnaeni, 2016). While the external legal protection made by the sovereign through regulation or regulation for the benefit of those who are weak, according to the nature of the rule of law should not be are favoring one party or one-sided. So proportionately obliged given a balanced legal the significance of as early as possible to the other party (Isnaeni, 2016). This can only occur at the beginning of establishing the Treaty, there is one party that is comparatively stronger than others, but in the implementation of the agreement of the parties that used to be strong that, stuck into the underdog, for example when the debtor tort, then both parties lender auction winner deserve legal protection. Based on legislation that the auction is selling like the selling of civil liability in General then the remedy is the same as a remedy in the event of civil law set in through appeals and cassation. Regulations implementing the auction has yet to provide legal certainty and protection to buyers of the auction means that right from the auction winner. This gave opportunities for parties who want to avail of the opportunity to do a lawsuit over implementation of the auction through KPKNL parate execution rights, particularly dependents. Based on a Supreme Court Circular letter No. 4 of the year 2014, then discharge the execution rights of a dependent object is no longer have to go through a lawsuit, auction winner can file execution discharge directly to the Chairman of the District Court.

Based on the discussion above, that the buyer or auction winner good intentioned over execution rights of a dependent process its bid via online (internet) the protection of the law, because:

in the auction process dependent rights online or via the internet is legal and binding, since the online auction process can be recorded in the auction server and serve as evidence of an electronic transaction or auction process, as regulated article 5 of law No. 11 of the year 2008.

Buyers of the auction or the auction winner will get treatise auctions and Auction Treatise, Grose as a proof of purchase that can be equated with a deed of Sale in the purchase of land rights in General. And can proceed with the process behind the names or the transition of land rights are registered in the national land Agency.

Discharge procedure on the ground that are purchased with the auction process, it is not necessary to mention the lawsuit to the State Court, but simply applying for discharge to the execution Chairman District Court.

\section{CONCLUSIONS}

Based on the findings in the study over the execution of guarantee of land-bound Dependent Rights online, then it can be used as a summary as follows:

Setting the execution dependent rights online in resolving the bad debt based on the regulation of the Minister of finance No.27/PMK.06/2016 jo No. 90/PMK.06/2016, determined as follows: submission of an auction conducted by the lender to KPKNL, 
appropriate domicile rights of a dependent Object and are furnished with the documents required in the process of auctions of rights to dependents. Auction announcement by Creditors as the applicant auction through print and electronic media. Auction bidding is done via ALE (electronic auction accounts) with the address : http:// www.lelangdjkn.kemenkeu.go.id. Implementation of auctions conducted done by lenders with Auction Officials class I as executor, and continued with the determination of the winner of the auction and published a treatise on the auction.

Legal protection of auction winner who made online are: legal protection internally to the lender as the seller auction or auction winner object as the object, then the auction purchaser protection law internally the transaction occurred before the auction of the object that is at the time of registration the auction by the lender to KPKNL, by providing information as-is (as to us) of the object of the auction. While the auction winner gets legal protection internally from the truth of the information Office of the auction and make a deal on the price had been offered in the implementation of the rights of a dependent object auction.Auction winner gets legal protection from the State in the implementation of the execution rights of a dependent as a legal protection that is externally, by establishing provisions on the procedures for Auction, as set in the regulation of the Minister The above mentioned financial, when set to be government regulations, in particular the rights of execution tangungan parate.The process behind the transitional name rights for the winners of the auction can be accelerated, so as to provide legal certainty. In an effort to discharge oyek auctions, auction winner can please help law enforcement authorities/ Police to do security.

\section{REFERENCES}

Anwar, M., Nidar, S. R., Komara, R., \& Layyinaturrobaniyah, L. (2019). Rural bank efficiency and loans for micro and small businesses: evidence from West Java Indonesia. International Journal of Emerging Markets. Retrieved from https://www.emerald.com/insight/content/ doi/10.1108/lJOEM-11-2017-0494/full/html

Bruggink, J. J. H. (2015). Refleksi Tentang Hukum, Pengertian-Pengertian Dasar Dalam Teori Hukum. PT Citra Aditya Bakti, Bandung.

Isnaeni, M. (2016). Pengantar Hukum Jaminan Kebendaan. Surabaya: PT. Revka Petra Media.

Marzuki, P. M. (2009). Penelitian Hukum. Jakarta: Kencana Prenada Media Group.

Soekanto, S., \& Mamudji, S. (2001). Penelitian Hukum Normatif: Suatu Tinjauan Singkat. Jakarta: PT. Raja Grafindo Persada.

Bruggink, J. J. H. (2015). Refleksi Tentang Hukum, Pengertian-Pengertian Dasar Dalam Teori Hukum. PT Citra Aditya Bakti, Bandung.

Isnaeni, M. (2016). Pengantar Hukum Jaminan Kebendaan. Surabaya: PT. Revka Petra Media.

Marzuki, P. M. (2009). Penelitian Hukum. Jakarta: Kencana Prenada Media Group.

Soekanto, S., \& Mamudji, S. (2001). Penelitian Hukum Normatif: Suatu Tinjauan Singkat. Jakarta: PT. Raja Grafindo Persada.

Putusan Mahkamah Agung RI nomor : 206 K/TUN/2017, Memeriksa Perkara Tata Usaha Negara Dalam Tingkat Kasasi, pada hari Selasa, tanggal 23 Mei 2017.

Putusan Mahkamah Agung RI Nomor 2626 K/Pdt/2014, memeriksa perkara perdata dalam tingkat kasasi. pada hari Rabu, tanggal 11 Maret 2015 